\title{
FGFR1 and PROKR2 rare variants found in patients with combined pituitary hormone deficiencies
}

\author{
Fernanda A Correa ${ }^{1}$, Ericka B Trarbach ${ }^{1}$, Cintia Tusset ${ }^{1}$, Ana Claudia Latronico ${ }^{1}$, \\ Luciana R Montenegro', Luciani R Carvalho', Marcela M Franca ${ }^{1}$, Aline P Otto', \\ Everlayny F Costalonga ${ }^{1}$, Vinicius $\mathbf{N}$ Brito ${ }^{1}$, Ana Paula Abreu ${ }^{4}$, Mirian Y Nishi ${ }^{1}$, \\ Alexander A L Jorge ${ }^{2}$, Ivo J P Arnhold ${ }^{1}$, Yisrael Sidis ${ }^{3}$, Nelly Pitteloud ${ }^{3}$ and \\ Berenice B Mendonca'
}

${ }^{1}$ Unidade de Endocrinologia do Desenvolvimento, Laboratório de Hormônios e Genética Molecular LIM42, and ${ }^{2}$ Unidade de Endocrinologia Genética, Laboratório de Endocrinologia Celular e Molecular LIM25, Hospital das Clínicas, Disciplina de Endocrinologia, Faculdade de Medicina da Universidade de São Paulo, Av. Dr. Eneas de Carvalho Aguiar, 255, 05403-000 São Paulo, Brazil

${ }^{3}$ Centre Hospitalier Universitaire Vaudois (CHUV), Faculté de Biologie et Médecine de I'Univesité de Lausanne, Lausanne, Switzerland

${ }^{4}$ Division of Endocrinology, Diabetes, and Hypertension, Brigham and Women's Hospital and Harvard Medical School, Boston, Massachusetts, USA

Massachusetts, USA

\begin{abstract}
The genetic aetiology of congenital hypopituitarism $(\mathrm{CH})$ is not entirely elucidated. FGFR1 and PROKR2 loss-of-function mutations are classically involved in hypogonadotrophic hypogonadism $(\mathrm{HH})$, however, due to the clinical and genetic overlap of $\mathrm{HH}$ and $\mathrm{CH}$; these genes may also be involved in the pathogenesis of $\mathrm{CH}$. Using a candidate gene approach, we screened 156 Brazilian patients with combined pituitary hormone deficiencies (CPHD) for loss-of-function mutations in FGFR1 and PROKR2. We identified three FGFR1 variants (p.Arg448Trp, p.Ser107Leu and p.Pro772Ser) in four unrelated patients (two males) and two PROKR2 variants (p.Arg85Cys and p.Arg248Glu) in two unrelated female patients. Five of the six patients harbouring the variants had a first-degree relative that was an unaffected carrier of it. Results of functional studies indicated that the new FGFR1 variant p.Arg448Trp is a lossof-function variant, while p.Ser107Leu and p.Pro772Ser present signalling activity similar to the wild-type form. Regarding PROKR2 variants, results from previous functional studies indicated that $p$.Arg85Cys moderately compromises receptor signalling through both MAPK and $\mathrm{Ca}^{2+}$ pathways while p.Arg248Glu decreases calcium mobilization but has normal MAPK activity. The presence of loss-of-function variants of FGFR1 and PROKR2 in our patients with CPHD is indicative of an adjuvant and/or modifier effect of these rare variants on the phenotype. The presence of the same variants in unaffected relatives implies that they cannot solely cause the phenotype. Other associated genetic and/or environmental modifiers may play a role in the aetiology of this condition.
\end{abstract}

\author{
Correspondence \\ should be addressed \\ to F A Correa \\ Email \\ fernandacorrea@usp.br
}

\footnotetext{
Key Words

- combined pituitary hormone deficiencies

- FGFR1

- PROKR2

- hypopituitarism
}

Endocrine Connections (2015) 4, 100-107 


\section{Introduction}

Combined pituitary hormone deficiencies (CPHD) are defined as the deficiency of two or more pituitary hormones. They can be associated with complex phenotypes such as cranial/facial midline defects and other extra-pituitary features. Mutations in transcription factors such as PROP1, POU1F1, GLI2, HESX1, LHX3, LHX4, SOX2, SOX 3 and OTX2 underlie CPHD $(1,2)$. There is clinical and genetic overlap between CPHD and isolated hypogonadotrophic hypogonadism $(\mathrm{IHH})$ and/or Kallmann syndrome (KS), such as midline cerebral and facial defects (3). The adenohypophyseal and olfactory placodes share a common embryological origin as they both emerge from the preplacodal field, which could explain this overlap (4).

FGFR1, a tyrosine kinase receptor, is expressed in Rathke's pouch and ventral diencephalon in the developing human embryo (5). PROKR2 is a G protein-coupled receptor essential for normal olfactory bulb development and sexual maturation in mice (6), and it is also involved in angiogenesis and neuronal migration (7).

Loss-of-function mutations in FGFR1 and PROKR2 are classically associated with IHH and/or KS $(8,9,10,11,12)$. Furthermore, mutations in FGFR1, PROKR2 and FGF8, the FGFR1 ligand, have already been found to be associated with hypothalamus-pituitary dysfunction $(3,5,13)$.

Our aim was to screen a large cohort of Brazilian patients with CPHD for loss-of-function mutations in FGFR1 and PROKR2 to investigate the role of these genes in the aetiology of hypopituitarism.

\section{Subjects and methods}

\section{Selection of patients}

We studied 156 Brazilian patients with CPHD recruited consecutively from the Hospital das Clinicas, University of Sao Paulo Medical School after approval of the ethical committee. In addition, informed written consent was obtained from patients and/or parents. The clinical and radiological features of this cohort are detailed in Supplementary Table 1 , see section on supplementary data given at the end of this article.

The diagnosis of CPHD was based on the failure to have a normal response to a combined pituitary stimulation test (0.05-0.1 U/kg insulin, $200 \mu \mathrm{g}$ thyrotrophin-releasing hormone and $100 \mu \mathrm{g}$ gonadotrophin-releasing hormone, i.v.) and/or low basal insulin-like growth factor 1 (IGF1), IGFbinding protein 3 , free thyroxine, luteinizing hormone (LH), follicle-stimulating hormone (FSH), oestradiol or (c) 2015 The authors Published by Bioscientifica Ltd testosterone and cortisol levels. Height was measured with a stadiometer, and height standard deviation was calculated using British references (14). Magnetic resonance imaging (MRI) scans were performed in a 1.5 Tesla unit (Sigma; GE, Milwaukee, WI, USA) using T1- and T2weighted sagittal and coronal scans. The control group consisted of 400 healthy Brazilian adults.

\section{Genetic analyses}

Genomic DNA was extracted from peripheral blood leucocytes by standard techniques. The entire coding region and exon-intron junctions of the FGFR1 (ENST00000341462) and PROKR2 (ENST00000217270) genes were amplified by PCR and sequenced, using primers and conditions described previously $(8,12)$. All mutations were confirmed in two separate PCR. The variants in DNA and protein sequences are presented according to HGSV nomenclature recommendations (www.hgvs.org/). Mutations in GLI2, LHX4, HESX1, OTX2 and SOX3 were searched for in the patients harbouring FGFR1 and PROKR2 variants.

\section{In silico analysis}

Computational analysis using algorithms from web-based tools such as Mutation Taster (http://www.mutationtaster. org/), SIFT (http://sift.jcvi.org/) and Polyphen-2 (http:// genetics.bwh.harvard.edu/pph2/) was performed for prediction of the pathological effects of the substitutions on protein sequence.

\section{Functional studies}

Luciferase reporter assays $~$ Signalling activity of FGFR1 mutants was assessed using L6 myoblast cells as described previously (15). In brief, cells were transiently transfected with WT or altered FGFR1c expression vector in combination with the osteocalcin FGF response element luciferase reporter. Cells were treated with increasing doses of FGF2 and assayed for luciferase activity. The data were plotted and fitted with threeparameter sigmoidal dose-response curves using Prism Software (version 5; GraphPad, La Jolla, CA, USA). Transfection experiments were performed in triplicate and repeated three times. Results of individual experiments were expressed as percentages of the WT value, and the calculated mean maximal activity (top of the curve) 
from three independent experiments was compared using Prisms' F-test function.

\section{Receptor expression and maturation studies *}

Endoglycosidase and western analysis were performed as described previously (15). In brief, COS-7 cells were transiently transfected with Myc-tagged WT or mutated FGFR1 cDNA. Samples of cleared cell lysate ( $4 \mu \mathrm{l}$, approximately $5 \mu \mathrm{g}$ of total protein) were subjected to PNGasef and EndoH digestion (New England Biolabs, Ipswich, MA, USA), resolved on NuPAGE 3-8\% Tris-acetate gels (Invitrogen) and then subjected to western analysis using an anti-Myc primary antibody (clone 4A6, 1:2000; Upstate Biotechnology, Inc., Lake Placid, NY, USA) and a goat antimouse HRP-conjugated secondary antibody (1:20 000; Upstate Biotechnology, Inc.). To control for equal loading, blots were stripped and reprobed with HRP-conjugated anti- $\beta$-actin antibody (1:20 000; Abcam, Cambridge, UK). FGFR1 and $\beta$-actin immunoreactivity was quantified by densitometry of film (BioMAx, Kodak) acquired images using ImageJ Software (Bethesda, MD, USA). Overall expression levels of WT and mutant receptors were determined from the PNGase-treated samples and were normalized to their respective $\beta$-actin levels. Results were expressed as the ratio between mutant and WT levels. For receptor maturation studies, the upper (mature) and lower (immature) band densities were determined individually from the EndoH-treated samples, and the percentage of the mature fraction was calculated and expressed as a ratio of mutant to WT expression. Experiments were repeated three times, and protein expression and maturation levels were compared between mutant and WT proteins using Student's $t$-test. Data are presented as the mean \pm s.E.M.

Cell surface expression - Expression of WT or mutant FGFR1 at the cell surface was quantified using COS-7 cells and an antibody binding assay (15). Experiments were performed in quadruplicate and repeated four times.
Specific cell-surface expression of altered FGFR1 proteins was compared with that of the WT protein using Student's $t$-test. Data are presented as the mean \pm s.e.M.

\section{Results}

\section{Genetic analyses}

We searched for variants in GLI2, LHX4, HESX1, OTX2 and SOX3 genes in the patients harbouring FGFR1 and PROKR2 variants. These genes are known to be involved in CPHD and no pathological mutations were found.

FGFR1 - Three missense variants, p.Ser107Leu, p.Arg448Trp and p.Pro772Ser, were identified in a heterozygous state in four unrelated patients (two males), the children of non-consanguineous parents (Table 1). Results of in silico analysis indicated that p.Arg448Trp is deleterious according to the Mutation Taster, SIFT and Polyphen-2 tools, whereas p.Ser107Leu and p.Pro772Ser were predicted to be disease-causing only by the Mutation Taster tool.

PROKR2 - Two missense variants, p.Arg85Cys and p.Arg248Glu, were found in a heterozygous state in two unrelated females, the children of non-consanguineous parents (Table 1). Results of in silico analysis indicated that p.Arg85Cys is damaging according to Mutation Taster, SIFT and Polyphen-2 whereas p.Arg248Glu was predicted to be benign using the three in silico prediction tools.

All the five variants have been detected previously in patients with congenital $\mathrm{HH}(9,16,17)$. The FGFR1 p.Pro772Ser variant was found in five out of 400 (1.25\%) Brazilian healthy controls, and the PROKR2 variant p.Arg85Cys was found in one out of $400(0.25 \%)$. The other three variants were not identified in Brazilian healthy controls.

Regarding population genetics, the FGFR1 variant p.Ser107Leu has a minor allele frequency (MAF) of $0.6 \%$

Table 1 Genotypes and functional in silico prediction of FGFR1 and PROKR2 variants found in patients.

\begin{tabular}{|c|c|c|c|c|c|c|c|}
\hline \multirow[b]{2}{*}{ Patient } & \multirow[b]{2}{*}{ Gene } & \multirow{2}{*}{$\begin{array}{l}\text { Nucleotide } \\
\text { change }\end{array}$} & \multirow[b]{2}{*}{ Protein change } & \multirow[b]{2}{*}{ Functional domain } & \multicolumn{3}{|c|}{ In silico prediction tools } \\
\hline & & & & & Mutation Taster & SIFT & Polyphen-2 \\
\hline I & FGFR1 & c. $320 \mathrm{C}>\mathrm{T}$ & p.Ser107Leu & Ig-like C2-type 1 domain & Disease-causing & Tolerated & Benign \\
\hline II & FGFR1 & c. $1342 C>T$ & p.Arg448Trp & Juxta-membrane domain & Disease-causing & $\begin{array}{l}\text { Affects protein } \\
\text { function }\end{array}$ & $\begin{array}{l}\text { Probably } \\
\text { damaging }\end{array}$ \\
\hline III & FGFR1 & c. $2314 \mathrm{C}>\mathrm{T}$ & p.Pro772Ser & C-terminal tail & Disease-causing & Tolerated & Benign \\
\hline IV & FGFR1 & c. $2314 \mathrm{C}>\mathrm{T}$ & p.Pro772Ser & C-terminal tail & Disease-causing & Tolerated & Benign \\
\hline V & PROKR2 & c. $253 \mathrm{C}>\mathrm{T}$ & p.Arg85Cys & First intracellular loop & Disease-causing & $\begin{array}{l}\text { Affects protein } \\
\text { function }\end{array}$ & $\begin{array}{l}\text { Probably } \\
\text { damaging }\end{array}$ \\
\hline VI & PROKR2 & c.743G $>A$ & p.Arg248Glu & Third intracellular loop & Polymorphism & Tolerated & Benign \\
\hline
\end{tabular}

http://www.endocrineconnections.org
DOI: $10.1530 /$ EC-15-0015
(C) 2015 The authors Published by Bioscientifica Ltd
This work is licensed under a Creative Commons Attribution-NonCommercial 4.0 International License. 
Table 2 Phenotypes of patients with FGFR1 and PROKR2 variants.

\begin{tabular}{|c|c|c|c|}
\hline Patient & Gene & Sex & $\begin{array}{c}\text { Age at } \\
\text { diagnosis (years) }\end{array}$ \\
\hline I & FGFR1 & $F$ & 15 \\
\hline II & FGFR1 & $F$ & 4 \\
\hline III & FGFR1 & M & 16 \\
\hline IV & FGFR1 & $M$ & 15 \\
\hline V & PROKR2 & $F$ & 19 \\
\hline VI & PROKR2 & $\mathrm{F}$ & 10 \\
\hline
\end{tabular}

\begin{tabular}{|c|c|}
\hline Hormonal deficiencies & MRI \\
\hline $\begin{array}{l}\text { GH, LH and FSH } \\
\text { GH, TSH, LH and FSH } \\
\text { GH, TSH, ACTH, LH and FSH } \\
\text { GH, TSH, LH and FSH } \\
\text { GH, ACTH, LH and FSH } \\
\text { GH, TSH, partial ACTH, LH } \\
\text { and FSH }\end{array}$ & $\begin{array}{l}\text { APH, EPP, normal stalk } \\
\text { APH, EPP, absent stalk } \\
\text { APH, EPP, thin stalk } \\
\text { APH, EPP, absent stalk } \\
\text { NAP, APP absent stalk } \\
\text { APH, EPP, absent stalk }\end{array}$ \\
\hline
\end{tabular}

\begin{tabular}{cll}
$\begin{array}{cll}\text { Smell } \\
\text { test }\end{array}$ & & Other features \\
\cline { 1 - 1 } $\mathrm{NL}$ & & Japanese ancestry \\
$\mathrm{NL}$ & & \\
$\mathrm{NL}$ & & Micropenis \\
$\mathrm{NL}$ & & Micropenis \\
$\mathrm{NL}$ & & Diabetes insipidus \\
$\mathrm{NL}$ & & $\begin{array}{c}\text { Diabetes mellitus, } \\
\text { facial asymmetry and } \\
\end{array}$ \\
& clinodactyly
\end{tabular}

F, female; M, male; APH, anterior pituitary hypoplasia; EPP, ectopic posterior pituitary; NAP, normal anterior pituitary; APP, absent posterior pituitary; NL, normal test.

considering all populations (ALL) of the 1000GENOMES project. Since the patient was born to Japanese parents, it is important to consider the MAF in the Japanese population, which is $2.8 \%$. The FGFR1 variant p.Pro772Ser has a MAF of $0.5 \%$ (ALL 1000GENOMES) and a MAF of $4.2 \%$ in African-American population of the Exome Sequencing Project (ESP6500). To date, the FGFR1 variant p.Arg448Trp has not been described in population databases.

The PROKR2 variant p.Arg85Cys has been described in the databases of the 1000GENOMES project $(\mathrm{MAF}=0.2 \%$ $\mathrm{ALL})$ and the ESP6500 project $(\mathrm{MAF}=0.6 \%)$ in the AfricanAmerican population. The PROKR2 variant p.Arg248Glu has no MAF described in databases. Phenotypes of patients carrying the variants are detailed in Table 2.

\section{Patients with FGFR1 variants}

p.Ser107Leu variant - The FGFR1 variant p.Ser107Leu was identified in a female patient born to non-consanguineous Japanese parents (patient I; Table 2). At first presentation, she was 15.5 years old and had severe short stature ( -7.6 S.D.), primary amenorrhoea and delayed bone age (10 years). Endocrine evaluation revealed growth hormone $(\mathrm{GH})$ and LH/FSH deficiencies. She was treated for both deficiencies, gained $15.7 \mathrm{~cm}$ and attained a final height of $131.7 \mathrm{~cm}$. Neuroimaging showed a small anterior pituitary, normal stalk and ectopic posterior pituitary. Her father was unavailable for genetic study and her mother was not a carrier of the variant, but her unaffected sister is a carrier of the same variant.

p.Arg448Trp variant $~$ The p.Arg448Trp variant was identified in a 4-year-old girl at first presentation (patient II; Table 2). She was born to non-consanguineous parents, and there was no history of short stature in her family.
The initial complaint was severe short stature ( -3.0 s.D.), and endocrine evaluation showed GH and thyroid-stimulating hormone (TSH) deficiencies. Both conditions were treated with good response and the patient achieved the family target height percentile. She had no pubertal signs until 13 years of age, and then puberty was induced with conjugated oestrogens. MRI revealed a small anterior pituitary, absent stalk and ectopic posterior pituitary. Her unaffected father and sister are carriers of the same variant.

p.Pro772Ser variant - We identified the $F G F R 1$ variant p.Pro772Ser in heterozygous state in two unrelated patients. The first patient (patient III; Table 1) had a history of breech presentation with forceps delivery. He first presented at age 16 years and 9 months with severe short stature ( -6.7 s.D.) and lack of sexual development with penile length of $4.5 \times$ $1.9 \mathrm{~cm}(<-2.5$ s.D. $)$, right testes $1.8 \times 1.0 \mathrm{~cm}$ and left testes $1.4 \times 0.9 \mathrm{~cm}$. He had GH, TSH, adrenocorticotrophic hormone (ACTH), LH and FSH deficiencies at laboratory evaluation. He was treated for all deficiencies and achieved a final height of $172.5 \mathrm{~cm}$ after 6 years of GH treatment. His unaffected mother is a carrier of the same variant.

The second patient harbouring this variant (patient IV; Table 1) was born at home without health assistance to non-consanguineous parents. At first presentation he was 15 years and 2 months old. The main complaints were short stature ( -3.5 S.D.) and lack of sexual development, with penile length $4.5 \times 1.5 \mathrm{~cm}(<-2.5$ s.D. $)$, the left testis was retractable and the right testis was $2.8 \times 1.5 \mathrm{~cm}$. Endocrine tests confirmed GH, TSH, LH and FSH deficiencies. He was treated for all deficiencies, and $\mathrm{GH}$ treatment was carried out for 3.5 years with growth to a final height of $172 \mathrm{~cm}$. At adulthood, he developed obesity class 3 and type 2 diabetes mellitus. His mother is not a carrier of the variant and his father was not available for testing.

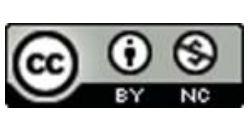

This work is licensed under a Creative Commons Attribution-NonCommercial 4.0 International License. 


\section{Patients with PROKR2 variants}

p.Arg85Cys variant $~$ The p.Arg85Cys variant was identified in a 19-year-old female eunuchoid patient who presented with primary amenorrhoea and no breast development (patient $\mathrm{V}$; Table 2). She was born to non-consanguineous parents. Endocrine tests revealed GH, ACTH, LH and FSH deficiencies. She also developed diabetes insipidus 8 years after the diagnosis of hypopituitarism. Neuroimaging revealed a normal anterior pituitary, absent stalk and a non-visualized posterior pituitary. Intriguingly, this patient reached normal final height $(168.3 \mathrm{~cm})$ without GH treatment. Her unaffected father carries the same variant.

p.Arg248Glu variant The female patient with p.Arg248Glu variant first presented at 10 years of age with severe short stature ( -5.0 s.D.; patient VI; Table 2 ). She was born to non-consanguineous parents at 32 gestational weeks by Caesarean section due to premature membrane rupture. Endocrine evaluation detected GH, TSH, LH, FSH and partial ACTH deficiencies. MRI revealed a small anterior pituitary, absent stalk and ectopic posterior pituitary. She has some dysmorphic features such as facial asymmetry and clinodactyly. She was treated for 8 years, until 18 years of age, for all deficiencies including GH and achieved a final height of $166.5 \mathrm{~cm}$. At 24 years old, she presented with diabetes mellitus and mild elevation of hepatic enzymes with negative serological test results for hepatitis and negative test results for autoimmune diabetes. Her unaffected mother carries the same variant. Her father died from alcoholic hepatic cirrhosis and had diabetes mellitus along with her brother and several uncles.

All the six patients were tested for olfactory function with The Pocket Smell Test or The Brief Smell Identification Test - Sensonics, Inc. (Haddon Heights, NJ, USA) and had a normal sense of smell.

\section{FGFR1 functional studies}

All the three FGFR1 variants were predicted to be pathogenic by at least one of the three prediction programmes

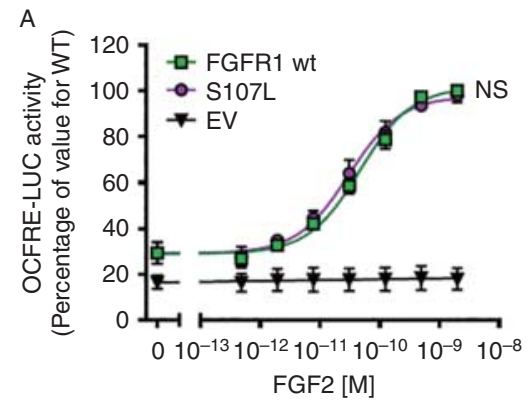

D
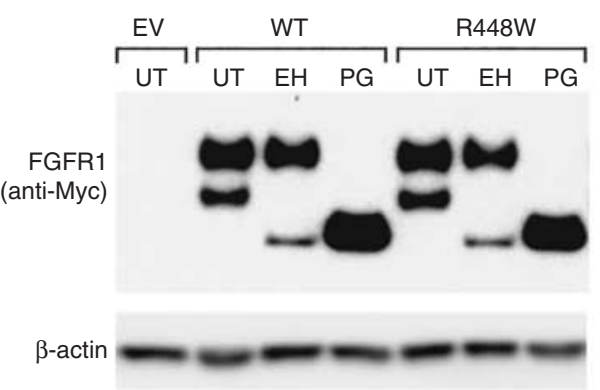
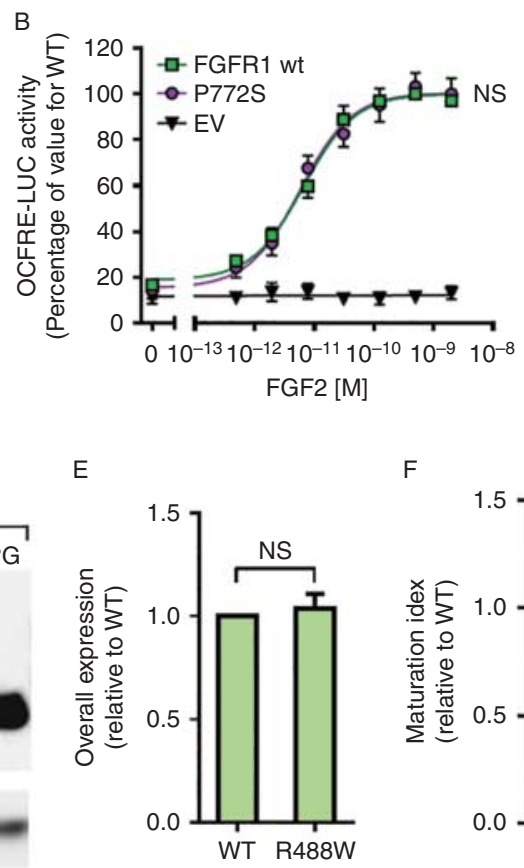

$\mathrm{F}$
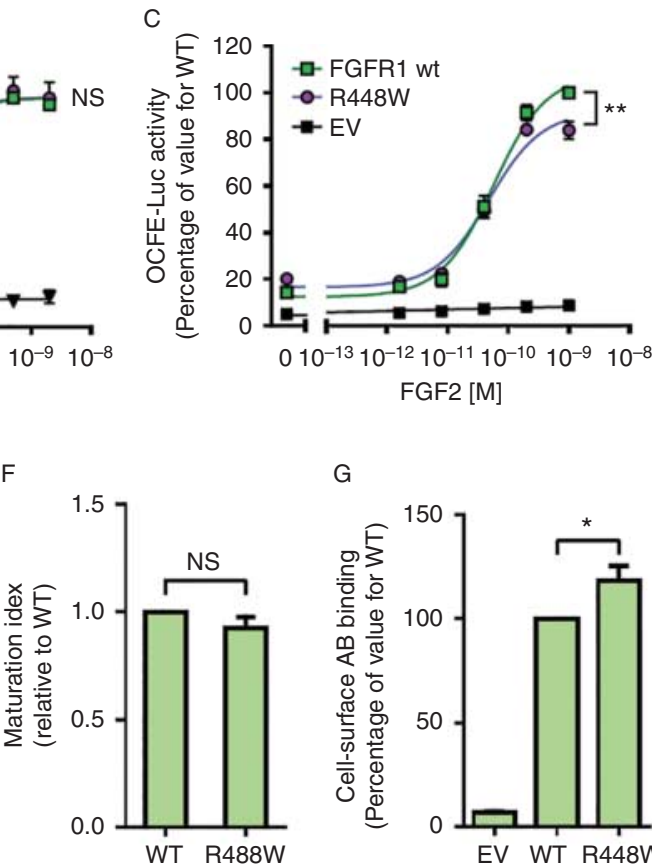

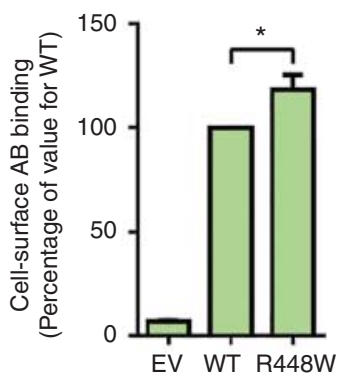

\section{Figure 1}

Functional analysis of FGFR1 variants. (A, B and C) Signalling activity of WT and altered FGFR1 receptors in L6 myoblasts. Plotted are means \pm s.E.M. of three independent experiments. p.Ser107Leu (A) and p.Pro772Ser (B) variants had normal signalling activity, while p.Arg448Trp had reduced maximal signalling activity (**statistically significant $(P<0.01)$ ) (C). (D) Western blot analysis of $\mathrm{CHO}$ cells transiently transfected with empty vector (EV), FGFR1 WT or p.Arg448Trp constructs. UT, untreated; EH, EndoH treated; PG, PNGase treated. (E and F) Densitometry analysis of total protein and maturation levels of WT and p.Arg448Trp receptors. Plotted are means \pm S.E.M. of three independent experiments. (G) Cell-surface expression levels of WT and p.Arg448Trp receptors assessed in live transiently transfected COS-7 cells. Plotted are means \pm s.E.M. of five independent experiments (*statistically significant $(P<0.05)$ ). http://www.endocrineconnections.org DOI: 10.1530/EC-15-0015
(C) 2015 The authors Published by Bioscientifica Ltd
This work is licensed under a Creative Commons Attribution-NonCommercial 4.0 International License. 
tested (Table 1). Signalling activity of these variants was assessed in vitro using the well-established FGF-responsive osteocalcin reporter system, which acts downstream of the MAPK pathway. Cells expressing the p.Ser107Leu and p.Pro772Ser variants elicited dose-response curves similar to the WT FGFR1c curve (Fig. 1A and B). The p.Arg448Trp variant, on the other hand, demonstrated a small (approximately 15\%) but significant reduction in maximal signalling activity $(P<0.01$; Fig. 1C). To evaluate potential molecular mechanisms underlying the observed reduced signalling activity, we performed protein expression studies. Overall protein expression and maturation levels of p.Arg448Trp were similar to those for the WT, indicative of normal protein synthesis and folding processes (Fig. 1D, E and F). However, cell-surface expression levels of this variant were significantly increased compared with the WT (approximately $20 \%, P<0.05$; Fig. 1G), indicating a defect in the receptor internalization process.

\section{Discussion}

Congenital hypopituitarism $(\mathrm{CH})$ is implicated in considerable morbidity and leads to premature mortality (18). Although many genetic causes have been discovered, the majority of patients remain without genetic diagnosis $(19,20,21)$. In this study, due to the clinical and genetic overlap between IHH/KS and CPHD, we investigated the presence of deleterious variants of two genes classically associated with $\mathrm{IHH} / \mathrm{KS}$ in a large cohort of Brazilian CPHD patients. We found four patients harbouring three different FGFR1 variants (p.Ser107Leu, p.Arg448Trp and p.Pro772Ser) and two patients with PROKR2 variants (p.Arg85Cys and p.Arg248Glu).

\section{Variants of FGFR1}

The first detection of FGFR1 defects in CPHD patients, to our knowledge, was the identification of a submicroscopic deletion including the FGFR1 gene in a male patient. This patient had GH, LH and FSH deficiencies associated with anosmia and spherocytosis (22). Another submicroscopic deletion involving FGFR1, identified during a study analysing 69 Japanese patients with CPHD, was detected in a female patient with CPHD associated with epilepsy, learning disability and Chiari type 1 malformation (23). In addition to the submicroscopic deletion, in this study, two heterozygous missense variants (p.Val102Iso and p.Ser107Leu) were also found in two unrelated patients. These variants were present at a low frequency in the Japanese control group. Results of functional studies of the two variants revealed nearly normal transactivating functions in luciferase assays (Table 3). The FGFR1 variant p.Ser107Leu was also found in our cohort, in a patient born to Japanese parents, as would be expected, we did not find the variant in our Brazilian control group. The functional study performed by us (Fig. 1) revealed no difference in transactivation in comparison with the WT, confirming the findings of the previous Japanese population study (23). Taking into account the presence of the variant in Japanese controls and population databases, an unaffected first-degree relative carrying the variant, and the in vitro data, it is unlikely that this variant (p.Ser107Leu) alone is causing the phenotype.

Concerning the p.Pro772Ser variant, due to its finding in five of the 400 healthy controls, a MAF of $4.2 \%$ in African-based populations - one of the major ethnic populations in Brazil - and the presence of an unaffected mother that carries this variant, it is reasonable to conclude that this is a polymorphism.

Table 3 Characteristics of FGFR1 missense variants found in patients with CPHD.

\begin{tabular}{|c|c|c|c|c|c|c|c|}
\hline \multirow[b]{2}{*}{ Variant } & \multirow{2}{*}{$\begin{array}{l}\text { Signalling } \\
\text { activity }\end{array}$} & \multirow[b]{2}{*}{ Expression } & \multicolumn{2}{|c|}{ Patients } & \multicolumn{2}{|c|}{ Controls } & \multirow[b]{2}{*}{ References } \\
\hline & & & $n$ & Frequency (\%) & $n$ & Frequency (\%) & \\
\hline p.Thr112Thr & NS & NS & $103^{a}$ & 3 & 268 & 0 & (3) \\
\hline p.Ser450Phe & $\downarrow \downarrow$ & $=$ & & & & 0 & \\
\hline p.Pro483Ser & $\downarrow \downarrow$ & $=$ & & & & 0 & \\
\hline p.Val102Ile & $\downarrow$ & NS & 69 & 3 & 100 & 2 & $(23)$ \\
\hline p.Ser107Leu & $=$ & NS & & & & 1 & \\
\hline p.Ser107Leu & $=$ & NS & 156 & 2 & 400 & 0 & Present study \\
\hline p.Arg448Trp & $\downarrow$ & NS & & & & 0 & \\
\hline p.Pro772Ser & $=$ & NS & & & & 1.25 & \\
\hline \multicolumn{8}{|c|}{$\begin{array}{l}\text { NS, not studied; }=\text {, similar to the WT. } \\
\text { a Patients with CPHD and/or SOD. }\end{array}$} \\
\hline \multicolumn{2}{|c|}{$\begin{array}{l}\text { http://www.endocrineconnections.org } \\
\text { DOI: } 10.1530 / \text { EC-15-0015 }\end{array}$} & Publish & $\begin{array}{l}\text { The aut } \\
\text { cientifica }\end{array}$ & & \multicolumn{3}{|c|}{$\begin{array}{l}\text { This work is licensed under a Creative Commons } \\
\text { Attribution-NonCommercial } 4.0 \text { International License. }\end{array}$} \\
\hline
\end{tabular}


The p.Arg448Trp variant, on the other hand, has not been described to date in population databases, it shows a reduced signalling activity, probably due to a defect in receptor internalization process (Fig. 1), and is considered deleterious according to three in silico prediction tools (Table 1). Taking into account all this information together, it is likely that this variant contributes to the phenotype, although first-degree relatives are unaffected carries. Also, the possibility of an oligogenic mechanism similar to that seen in IHH/KS (17) cannot be discarded.

In an additional study focusing on the genetic overlap in KS, CPHD and septo-optic dysplasia (SOD), a cohort of 103 patients was examined. Three heterozygous variants (p.Thr112Thr, p.Ser450Phe and p.Pro483Ser) were found in FGFR1 in three different unrelated patients with CPHD and SOD. The latter two variants showed decreased signalling activity in luciferase reporter assays and similar overall expression and maturation levels in western blotting analysis (3).

In summary, considering the present study and the previously published data for the two other cohorts described above $(3,23)$, to date, a total of 328 patients with CPHD and/or SOD have been screened for FGFR1 mutations, and nine patients $(2.7 \%)$ were found to harbour eight different heterozygous FGFR1 variants with variable probabilities of having a significant role in the phenotype (Table 3 ).

\section{Variants of PROKR2}

PROKR2 mutations have been previously screened for in patients with $\mathrm{CH}$. Reynaud and colleagues screened 72 patients with pituitary stalk interruption syndrome (PSIS) and found three heterozygous missense variants (p.Leu173Arg, p.Arg85His and p.Ala51Thr). The first two showed deleterious effects in functional studies supporting, according to the authors, a causative role to the phenotype (24). McCabe and colleagues (25) screened 422 patients with $\mathrm{CH}$, holoprosencephaly and/or SOD and found five missense variants in 11 unrelated patients, three of them (p.Arg85Leu, Leu173Arg and Arg268Cys) proved to be deleterious in functional studies. In the latter study, the p.Leu173Arg variant was inherited by the patient from his unaffected mother, who was proven to be homozygous for the variant. The poor genotype-phenotype correlation led the authors to conclude that the contribution of PROKR2 variants to the phenotype is uncertain (25).

The PROKR2 variants found in our cohort of 156 patients have not been previously described in $\mathrm{CH}$, PSIS or SOD, but have already been described in patients with $\mathrm{KS} / \mathrm{IHH}$ and have been submitted to functional studies
$(16,26,27)$. The p.Arg85Cys variant showed modest but a significant $30 \%$ reduction in maximal MAPK activation in an Egr1-Luc assay (26). In inositol phosphatidyl (IP) accumulation assays, the variant showed similar doseresponse curves to WT PROKR2. Also, the p.Arg85Cys variant does not interfere with PROK2 ligand binding and its plasma membrane expression is not reduced according to the results of western blot analyses (26). Our patient inherited the variant from an unaffected father.

The p.Arg248Glu variant is located within the last intracellular loop, and results of functional analyses revealed normal transcription activity in an Erg-Luc assay but decreased calcium mobilization activity (72\% of WT) in an aequorin-based $\mathrm{Ca}^{2+}$ flux assay. Its expression level was similar to that of the WT PROKR2 in western blot experiments (16). This variant does not have a MAF described in population databases and the patient's mother is an unaffected carrier.

To date, including our cohort, 650 patients with CPHD and/or SOD have been studied for PROKR2 mutations and 16 patients (2.5\%) harbour eight different heterozygous PROKR2 variants. Functional studies have been performed on all variants and six of them were proved to be at least partially deleterious.

In conclusion, FGFR1 and PROKR2 variants may contribute to the phenotype of patients with CPHD but are unlikely to be implicated in isolation. Consistently with the results of previous studies, we believe that it is likely that other associated genetic and/or environmental factors are involved in the aetiology of this condition.

\section{Supplementary data}

This is linked to the online version of the paper at http://dx.doi.org/10.1530/ EC-15-0015.

Declaration of interest

The authors declare that there is no conflict of interest that could be perceived as prejudicing the impartiality of the research reported.

\section{Funding}

This work was supported by grants 305743/2011-2 (to B B Mendonca) and 304678/2012-0 (to A A L Jorge) from the National Council for Scientific and Technological Development (CNPq), and grant 2013/03236-5 (to A A L Jorge) from the Sao Paulo Research Foundation (FAPESP).

\section{References}

1 Davis SW, Castinetti F, Carvalho LR, Ellsworth BS, Potok MA, Lyons RH, Brinkmeier ML, Raetzman LT, Carninci P, Mortensen AH et al. Molecular mechanisms of pituitary organogenesis: in search of novel regulatory genes. Molecular and Cellular Endocrinology 2010323 4-19. (doi:10.1016/j.mce.2009.12.012) 
2 Kelberman D, Rizzoti K, Lovell-Badge R, Robinson IC \& Dattani MT. Genetic regulation of pituitary gland development in human and mouse. Endocrine Reviews 200930 790-829. (doi:10.1210/er.2009-0008)

3 Raivio T, Avbelj M, McCabe MJ, Romero CJ, Dwyer AA, Tommiska J, Sykiotis GP, Gregory LC, Diaczok D, Tziaferi V et al. Genetic overlap in Kallmann syndrome, combined pituitary hormone deficiency, and septo-optic dysplasia. Journal of Clinical Endocrinology and Metabolism 201297 E694-E699. (doi:10.1210/jc.2011-2938)

4 Streit A. The preplacodal region: an ectodermal domain with multipotential progenitors that contribute to sense organs and cranial sensory ganglia. International Journal of Developmental Biology $2007 \mathbf{5 1}$ 447-461. (doi:10.1387/ijdb.072327as)

5 McCabe MJ, Gaston-Massuet C, Tziaferi V, Gregory LC, Alatzoglou KS, Signore M, Puelles E, Gerrelli D, Farooqi IS, Raza J et al. Novel FGF8 mutations associated with recessive holoprosencephaly, craniofacial defects, and hypothalamo-pituitary dysfunction. Journal of Clinical Endocrinology and Metabolism 201196 E1709-E1718. (doi:10.1210/jc.2011-0454)

6 Matsumoto S, Yamazaki C, Masumoto KH, Nagano M, Naito M, Soga T, Hiyama H, Matsumoto M, Takasaki J, Kamohara M et al. Abnormal development of the olfactory bulb and reproductive system in mice lacking prokineticin receptor PKR2. PNAS 2006103 4140-4145. (doi:10.1073/pnas.0508881103)

7 Lin DC, Bullock CM, Ehlert FJ, Chen JL, Tian H \& Zhou QY. Identification and molecular characterization of two closely related $\mathrm{G}$ protein-coupled receptors activated by prokineticins/endocrine gland vascular endothelial growth factor. Journal of Biological Chemistry 2002277 19276-19280. (doi:10.1074/jbc.M202139200)

8 Abreu AP, Trarbach EB, de Castro M, Frade Costa EM, Versiani B, Matias Baptista MT, Garmes HM, Mendonca BB \& Latronico AC. Loss-of-function mutations in the genes encoding prokineticin-2 or prokineticin receptor- 2 cause autosomal recessive Kallmann syndrome. Journal of Clinical Endocrinology and Metabolism 200893 4113-4118. (doi:10.1210/jc.2008-0958)

9 Dodé C, Levilliers J, Dupont JM, De Paepe A, Le Dû N, Soussi-Yanicostas N, Coimbra RS, Delmaghani S, Compain-Nouaille S, Baverel F et al. Lossof-function mutations in FGFR1 cause autosomal dominant Kallmann syndrome. Nature Genetics 200333 463-465. (doi:10.1038/ng1122)

10 Dodé C, Teixeira L, Levilliers J, Fouveaut C, Bouchard P, Kottler ML, Lespinasse J, Lienhardt-Roussie A, Mathieu M, Moerman A et al. Kallmann syndrome: mutations in the genes encoding prokineticin-2 and prokineticin receptor-2. PLoS Genetics 20062 e175. (doi:10.1371/ journal.pgen.0020175)

11 Pitteloud N, Zhang C, Pignatelli D, Li JD, Raivio T, Cole LW, Plummer L, Jacobson-Dickman EE, Mellon PL, Zhou QY et al. Loss-of-function mutation in the prokineticin 2 gene causes Kallmann syndrome and normosmic idiopathic hypogonadotropic hypogonadism. PNAS 2007 104 17447-17452. (doi:10.1073/pnas.0707173104)

12 Trarbach EB, Costa EM, Versiani B, de Castro M, Baptista MT, Garmes HM, de Mendonca BB \& Latronico AC. Novel fibroblast growth factor receptor 1 mutations in patients with congenital hypogonadotropic hypogonadism with and without anosmia. Journal of Clinical Endocrinology and Metabolism 200691 4006-4012. (doi:10.1210/jc.2005-2793)

13 Asakura Y, Muroya K, Hanakawa J, Sato T, Aida N, Narumi S, Hasegawa T \& Adachi M. Combined pituitary hormone deficiency with unique pituitary dysplasia and morning glory syndrome related to a heterozygous PROKR2 mutation. Clinical Pediatric Endocrinology 2015 24 27-32. (doi:10.1297/cpe.24.27)

14 Tanner JM, Whitehouse RH \& Takaishi M. Standards from birth to maturity for height, weight, height velocity, and weight velocity: British children, 1965, II. Archives of Disease in Childhood 196641 613-635. (doi:10.1136/adc.41.220.613)
15 Raivio T, Sidis Y, Plummer L, Chen H, Ma J, Mukherjee A, JacobsonDickman E, Quinton R, Van Vliet G, Lavoie H et al. Impaired fibroblast growth factor receptor 1 signaling as a cause of normosmic idiopathic hypogonadotropic hypogonadism. Journal of Clinical Endocrinology and Metabolism 200994 4380-4390. (doi:10.1210/jc.2009-0179)

16 Cole LW, Sidis Y, Zhang C, Quinton R, Plummer L, Pignatelli D, Hughes VA, Dwyer AA, Raivio T, Hayes FJ et al. Mutations in prokineticin 2 and prokineticin receptor 2 genes in human gonadotrophinreleasing hormone deficiency: molecular genetics and clinical spectrum. Journal of Clinical Endocrinology and Metabolism 200893 3551-3559. (doi:10.1210/jc.2007-2654)

17 Sykiotis GP, Plummer L, Hughes VA, Au M, Durrani S, Nayak-Young S, Dwyer AA, Quinton R, Hall JE, Gusella JF et al. Oligogenic basis of isolated gonadotropin-releasing hormone deficiency. PNAS 2010107 15140-15144. (doi:10.1073/pnas.1009622107)

18 Tomlinson JW, Holden N, Hills RK, Wheatley K, Clayton RN, Bates AS, Sheppard MC \& Stewart PM. Association between premature mortality and hypopituitarism. West Midlands Prospective Hypopituitary Study Group. Lancet 2001357 425-431. (doi:10.1016/S01406736(00)04006-X)

19 Izumi Y, Suzuki E, Kanzaki S, Yatsuga S, Kinjo S, Igarashi M, Maruyama T, Sano S, Horikawa R, Sato N et al. Genome-wide copy number analysis and systematic mutation screening in 58 patients with hypogonadotropic hypogonadism. Fertility and Sterility 2014102 1130-1136.e3. (doi:10.1016/j.fertnstert.2014.06.017)

20 Mehta A, Hindmarsh PC, Mehta H, Turton JP, Russell-Eggitt I, Taylor D, Chong WK \& Dattani MT. Congenital hypopituitarism: clinical, molecular and neuroradiological correlates. Clinical Endocrinology 2009 71 376-382. (doi:10.1111/j.1365-2265.2009.03572.x)

21 Osorio MG, Marui S, Jorge AA, Latronico AC, Lo LS, Leite CC, Estefan V, Mendonca BB \& Arnhold IJ. Pituitary magnetic resonance imaging and function in patients with growth hormone deficiency with and without mutations in GHRH-R, GH-1, or PROP-1 genes. Journal of Clinical Endocrinology and Metabolism 200287 5076-5084. (doi:10.1210/jc.2001-011936)

22 Vermeulen S, Messiaen L, Scheir P, De Bie S, Speleman F \& De Paepe A. Kallmann syndrome in a patient with congenital spherocytosis and an interstitial 8p11.2 deletion. American Journal of Medical Genetics 2002 108 315-318. (doi:10.1002/ajmg.10295)

23 Fukami M, Iso M, Sato N, Igarashi M, Seo M, Kazukawa I, Kinoshita E, Dateki S \& Ogata T. Submicroscopic deletion involving the fibroblast growth factor receptor 1 gene in a patient with combined pituitary hormone deficiency. Endocrine Journal 201360 1013-1020. (doi:10.1507/endocrj.EJ13-0023)

24 Reynaud R, Jayakody SA, Monnier C, Saveanu A, Bouligand J, Guedj AM, Simonin G, Lecomte P, Barlier A, Rondard P et al. PROKR2 variants in multiple hypopituitarism with pituitary stalk interruption. Journal of Clinical Endocrinology and Metabolism 201297 E1068-E1073. (doi:10.1210/jc.2011-3056)

25 McCabe MJ, Gaston-Massuet C, Gregory LC, Alatzoglou KS, Tziaferi V, Sbai O, Rondard P, Masumoto KH, Nagano M, Shigeyoshi Y et al. Variations in PROKR2, but not PROK2, are associated with hypopituitarism and septo-optic dysplasia. Journal of Clinical Endocrinology and Metabolism 201398 E547-E557. (doi:10.1210/jc.2012-3067)

26 Abreu AP, Noel SD, Xu S, Carroll RS, Latronico AC \& Kaiser UB. Evidence of the importance of the first intracellular loop of prokineticin receptor 2 in receptor function. Molecular Endocrinology 201226 1417-1427. (doi:10.1210/me.2012-1102)

27 Monnier C, Dode C, Fabre L, Teixeira L, Labesse G, Pin JP, Hardelin JP \& Rondard P. PROKR2 missense mutations associated with Kallmann syndrome impair receptor signalling activity. Human Molecular Genetics 200918 75-81. (doi:10.1093/hmg/ddn318)

Received in final form 5 March 2015

Accepted 10 March 2015 http://www.endocrineconnections.org

DOI: 10.1530/EC-15-0015
(C) 2015 The authors Published by Bioscientifica Ltd
This work is licensed under a Creative Commons Attribution-NonCommercial 4.0 International License. 